\title{
STUDIES OF THE LEUKOCYTES IN PULMONARY TUBERCULOSIS AND PNEUMONIA*
}

\author{
JAMES ALEXANDER MILLER, M.D., AND MARGARET A. REED, A.B. \\ NEW YORK
}

It has long been recognized that the leukocytes of the circulating blood play an important rôle in many, if not all, bacterial infections, and numerous investigations have already contributed valuable additions to our knowledge of this subject.

The researches of Arneth, calling attention to the morphology of the nucleus in the neutrophil leukocytes, especially in tuberculosis, have stimulated further studies in this direction on the part of various observers. The results reported in this paper were first suggested by the work of Arneth and represent an effort to corroborate and amplify his results by various experimental and clinical observations and especially to determine their value in the diagnosis and prognosis of pulmonary tuberculosis and pneumonia.

It seemed possible that Arneth had laid undue emphasis on the significance of the neutrophil leukocytes and that it was important to study the other forms of leukocytes in connection with them. Pneumonia was chosen as a companion study with pulmonary tuberculosis, as forming a contrast of an acute with a chronic pulmonary disease.

An effort has been made to collect the information which is widely distributed in the literature, and by correlating our own results with that of others, to try to present a fairly complete study of the behavior of the white blood-cells in these two diseases.

The clinical material was obtained from the tuberculosis clinic, day camp and wards of Bellevue Hospital, and in the case of pneumonia from the medical wards of Bellevue Hospital, many of the cases observed being under the services of Dr. George R. Lockwood and Dr. William K. Draper, to both of whom we are deeply indebted for the privilege of studying these cases.

\section{THE LECKOCYTES IN NORMAL INDIVIDUALS}

As a basis of such a study, it is essential to establish the normal conditions both as to total number of leukocytes in the blood and as to their distribution among the various classes as shown by the differential count.

* Read before the American Climatological Association in Montreal, Can., June, 1911; received for publication Dec. 1, 1911. 
Almost all authorities place the normal number from 5,000 to 10,000 per cubic millimeter. The text-books have evidently appropriated these results from the earlier observations of Hayem, ${ }^{1} \mathrm{Tür}^{2}{ }^{2}$ Grawitz, ${ }^{3} \mathrm{Naegeli}^{4}$ and others. A recent careful study by Kjer-Petersen, ${ }^{5}$ however, places the average normal number between 4,000 and 5,000 in men and comes to the conclusion that in women the normal count is very irregular, varying from 4,000 to 25,000 under various physiological conditions.

This observer lays great stress on the fact that the blood is often not homogeneous, this being especially apt to be the case in women. $\mathrm{He}$ attributes the higher counts usually noted to improper methods, laying particular stress on the necessity of taking the specimen of blood when the subject is fasting before breakfast and also on the importance of invariable close approximation of the cover-slip to the counting chamber so as to produce Newton's rings. Arneth, Steffen and others agree with Kjer-Petersen. In our own studies we found the average number of leukocytes in a large number of counts to be 9,000 .

In the normal differential count there is considerable variation among the various authorities. This is largely due, however, to the fact that there is no unanimity of opinion as to what types of cells are included in the various groups. Table 1 gives the figures quoted by several independent observers.

Table 1.-Normal Differential Count.

Poly- Trans- Large Large Small Eosino- Baso-

nu- ition- Mono- Lym- Lympho- phils. phils.

clears als. nu- phocytes. cytes. .... ...

$\ldots \ldots$ clears. $\ldots$... $\ldots$. $\ldots$. $\ldots$

\begin{tabular}{|c|c|c|c|c|c|c|c|}
\hline Cabot ${ }^{3}$ & $\ddot{62-70}$ & $\cdots$ & clears. & $\ddot{4-8}$ & $\ddot{20-30}$ & $\ddot{0.5-4}$ & $\ddot{1 / 45-0.9}$ \\
\hline Ewing" & $70 \cdot 72$ & 2 & 4 & 22 & 25 & $2-4$ & $0.5-2$ \\
\hline Wood & $65-75$ & $2-4$ & 1 & 22 & 25 & $2-4$ & 0.5 \\
\hline Naegeli4 & 65.70 & 3 & 5 & 22 & 25 & $2-4$ & 0.5 \\
\hline Webb and Williams ${ }^{2}$. & 54 & $\cdots$ & $\cdots$ & 24 & 19 & 2 & 0.4 \\
\hline Da $\operatorname{Costa}^{10} \ldots \ldots \ldots$ & $60-75$ & 4 & 8 & $\ldots$ & $20-30$ & 0.5-5 & 0.5 \\
\hline
\end{tabular}

Many emphasize the importance of calculating the actual number of each class of cells rather than indicating the results by percentages. In our work we have discarded the terms "transitional" and "large mono-

1. Hayem: Le sang et ses alterations anatomiques, Paris, 1899, G. Masson.

2. Türk: Verhalten des Blutes bei akuten Infektionskrankheiten, Vienna, 1898, W. Braumiller.

3. Grawitz: Hæmatologie, Leipsic, 1907, G. Thieme; Klinische Pathologie des Blutes, Berlin, 1902, O. Enslin; Berl. klin. Wchnschr., 1894, xxxi, 100.

4. Naegeli : Blutkrankheiten und Blutdiagnostik, Leipsic, 1907, Veit and Co.

5. Kjer-Petersen: Beitr. z. Klin. d. Tuberk., 1906, Supp.-Vol. i.

6. Cabot: Clinical Examination of the Blood, New York, 1904, William Wood and Co.

7. Ewing: Clinical Pathology of the Blood, New York and Phila., 1903, Lea Brothers and Co.

8. Wood: Chemical and Microscopical Diagnosis, New York, 1909, D. Appleton and Co.

9. Webb and Williams: Tr. Nat. Assn. Prev. Tub., 1909, v, 231.

10. Da Costa: Clinical Hematology, Phila., 1905, P. Blakiston's Son and Co. 
nuclear," and in our differential count these cells, as described by others, are probably partly included in the polynuclears and partly in the large lymphocytes.

\section{THE BIOLOGY OF THE LEUKOCYTES}

In order to understand properly the significance of the differential count of the leukocytes, particularly the work of Arneth, ${ }^{11}$ it is valuable to summarize briefly the theories concerning the development of the leukocyte.

There are two general theories regarding this development, dividing hematologists into two distinct schools. One, under the leadership of Ehrlich, ${ }^{12}$ considers that the polynuclear neutrophils, eosinophils and baso. phils are derived only from their corresponding marrow-cells and that there is never a transition from the lymphocytes to the polynuclear forms. The lymphocyte, according to this school, develops from the various lymphoid organs, some even from lymphoid tissue in the marrow and pass through the various stages of lymphoblasts, large lymphocytes and small lymphocytes, but never into the types of cells with granular cell bodies.

The large mononuclears and transitional cells, according to this school, are separate entities derived from the marrow and the transitional cells probably are derived from large mononuclears and in turn are trans-

11. Arneth: Die neutrophilen weissen Blutkörperchen bei Infektionskrank. heiten, Jena, 1904; G. Fischer; Zum Verhalten der neutrophilen Leukozyten bei Infektionskrankheiten, Mïnchen. med. Wchnschr., 1904, li, 1097; Die agonale Leukozytose, München. med. Wchnschr., 1904, Ii, 1195; Experimentelle Untersuchungen zum Verhalten der weissen (und roten) Blutkörperchen bei Infektions und Intoxikationsversuchen, sowie nach Einverleibung von Eiweisskörpern und Heilseris, Ztschr. f. klin. Med., 1905, lvii, 288; München. med. Wchnschr., 1904, li, 1993; Die kachektische Leukozytose; Verhalten der neutrophilen Leukozyten beim Carcinom, Ztschr. f. klin. Med., 1904, liv, 238; Blutuntersuchungen bei der Tuberkulose der Lungen und bei der Tuberkulinkur, München. med. Wchnschr., 1905, Iii, 542; Die Lungenschwindsucht auf Grundlage klinischer und experimenteller hæmatologischer Untersuchungen, Ztschr. f. Tub., 1905, vii, 309, 405; Erwiderung zu Hiller's Beitrage zur Morphologie der neutrophilen Leukozyten und ihrer klinischen Bedeutung, Folia Hæmatologica, 1905, ii, 169; Zu meinen Blutuntersuchung (Nachprüfungen, einige weitere Beitrage), Erwiderung zu Flesch und Schossberger, Deutsch. Arch. f. klin. Med., 1906, lxxxvii, 209; H. Pollitzer's Anschauungen, über die Kernbeschaffenheit der neutrophilen Leukozyten unter normalen und pathologischen Verhältnisse, Wien. med. Wchnschr, 1907, lvii, 430; Entgegnung zu H. Pollitzer's zu Arneth's Verschiedung, etc., Deutsch. Arch. f. klin. Med., 1908, xciv, 217; Zu H. Pollitzer's Beitrage zur Morphologie und Biologie, etc., Folia Hæmatologica, 1908, vi, 210; Zu Paulicek: Zur qualitativen Blutuntersuchung nach der von Arneth angegebenen Methode, Folia Hæmatologica, Supplement, 1907, 167; Entgegnung zu Bourmoff und Brugsch: Das neutrophile Blutbild bei Infektionskrankheiten, Ztschr. f. klin. Med., 1907, lxiv, 170; Das Neutrophile Blutbild bei Infektionskrankheiten. Gegenerwiderung zur Antwort van. T. Brugsch, etc., Ztschr. f. klin. Med., 1908, lvi, 192; Diagnose und Therapie der Anaemien, Würzburg, 1907; A. Stuber: Die Leukozytose in der Schwangerschaft, etc., und die Leukozytose der Neugeborenen, Arch. f. Gynäkol., 1904, lxxiv, 145.

12. Ehrlich: Farbenanalytische Untersuchungen z. Histologie u. Klinik des Blutes, Berlin, 1891, A. Hirschwald. 
formed into neutrophils. Pappenheim, ${ }^{13}$ Naegeli, ${ }^{4}$ Weidenreich ${ }^{14}$ and the majority of observers now accept this theory.

The other theory, which is held by the Russian school under the leadership of Uskow, and which is also supported by Grawitz, holds that the neutrophil cells are frequently derived from the lymphocytes, and that the so-called transitionals often represent a stage between these two types of cells.

Practically all authorities agree that the true lymphocytes do not act as phagocytes, although it has been demonstrated that they do in some way hinder the development of the bacterial infection in the body.

In the development of the neutrophils, Arneth's contention is that their progress from the myelocyte is marked by changes in the nucleus, it being first indented and bent and finally lobulated, the mononuclear forms, therefore, representing the younger and the multimononuclear forms the older type of cells. The granules also are more numerous in the older cells. In the younger cells the granules are apt to be first basophilic and later oxyphilic. The origin and significance of the eosinophils have been carefully studied by Brown, but accurate scientific knowledge of them is still lacking.

\section{ARNETH'S BLOOD-PICTURE}

In developing his theory of the changes of the nucleus during the growth of the neutrophil, Arneth has divided the neutrophils into various classes according to the number and shape of the nuclear segments. This he tabulates into a very involved blood-picture. His contention, supported by numerous clinical observations, is that in various diseases the differential count of the neutrophils, according to his scheme, very often shows an abnormal predominance of the younger forms of cells, which he calls a shifting to the left in his blood-picture, that this shifting is very characteristic and represents a definite reaction on the part of the organism to the infection, and that a study of these changes forms a valuable basis for the differentiation of diseases and knowledge of their clinical course and subsequent history.

Arneth's work has attracted a good deal of attention and many reports based on his theory have appeared in the literature. Hiller, ${ }^{15}$ in addition to finding Arneth's method unreliable clinically because of the great variations in the normal, and because of the fact that the changes noted bore no relation to the severity of the disease, disagrees with the theory of Arneth, contending that the neutrophils are derived from lymphocytes. Pappenheim ${ }^{13}$ successfully refutes his contentions. Pollitzer ${ }^{18}$ dissents

13. Pappenheim: Folia Hæmatologica, 1905, 166; Atlas d. menschliche Blutzellen, Jena, 1905, G. Fischer.

14. Weidenreich: Arch. f. microse. Anat., 1908, lxxii, 209.

15. Hiller: Folia Hæmatologica, 1905, 85.

16. Pollitzer: Wien. ned. Wchnschr., 1906, lvi, 862; Deutsch. Arch. f. klin. Med., 1907, xcii, 1; Ztschr. f. Heilk., 1907, Section f. Path. Anat., viii, 239. 
very strongly from Arneth as to his theory of development of the nucleus, and also holds that the changes in the nucleus noted are due to artefacts caused by the method of staining.

Arneth's reply to our own investigations discredits Pollitzer's contentions. Busse ${ }^{17}$ objects on the ground that experiments showed that there was no variation of phagocytic power among the different classes of neutrophils according to the number of nuclear segments. He consequently argues against Arneth's conclusions that these variations in the nucleus denote variations in efficiency against infection. Arneth, in his reply, denies the importance of these observations.

Zangemeister and Ganz ${ }^{18}$ object to Arneth's method of considering the neutrophils to the exclusion of the other forms of leukocytes and also to Arneth's classification. Their experiments with streptococci tend to show that the mononuclear neutrophils are the most important from the standpoint of prognosis, the polynuclear neutrophils and the eosinophils coming next in order.

Flesch and Schossberger ${ }^{19}$ studied many diseases in children, and while agreeing to the fact that the shifting to the left did occur under various conditions, found that this shift had no relation to the clinical course of the disease. Pollicek ${ }^{20}$ also found that in tuberculosis the bloodpicture was of no value clinically either in diagnosis or prognosis. Bourmoff and Brugsch ${ }^{21}$ came to similar conclusions. In this country Kagann ${ }^{22}$ and Solis Cohen and Strickler ${ }^{23}$ found Arneth's method of no clinical value.

Many other observers, however, particularly recently, have corroborated Arneth. Among these are Bochenski, ${ }^{24}$ Kownatski ${ }^{25}$ and Grafenberg $^{28}$ in sepsis, particularly in puerperal fever; Kohl ${ }^{27}$ and Kothe ${ }^{28}$ in appendicitis, Sonnenberg and $K_{\text {othe }}{ }^{29}$ in peritonitis, Esser ${ }^{30}$ in intestinal diseases of children and Lewinson in several diseases, found Arneth's method of value both in diagnosis and prognosis. Many others have corroborated Arneth's methods in tuberculosis. These will be noted more in detail later.

17. Busse: München. med. Wehnschr., 1910, lvii, 70.

18. Zangemeister and Ganz: München. med. Wchnschr., 1909, lvi, 793.

19. Flesch and Schossberger: Jahrb. f. Kinderheilk., 1905, lxii, 249.

20. Paulicek: Folia Hæmatologica, 1907, iv, 751.

21. Bourmoff and Brugsch: Ztschr. f. klin. Med., 1907, Ixiii, 489.

22. Kagan: Boston Med. and Surg. Jour., 1910, clxii, 709.

23. Solis Cohen and Strickler: New York Med. Jour., 1910, xcii, 248.

24. Bochenski: Gynäkol. Rundschau, 1909, iii, 148.

25. Kownatzki: Beitr. z. Geburtsh. u. Gynäkol., 1906, x, 275.

26. Grafenberg: Arch. f. Gynäkol., 1908, lxxxv, 302.

27. Kohl: Mitt. a. d. Grenzgeb. d. Med. u. Chir., 1911, xxii, 542.

28. Kothe: Berl. klin. Wchnschr., 1908, xlv, 1633; München. med. Wchnschr., 1909 , Ivi, 1130 .

29. Sonnenberg and Kothe: Deutseh. Ztschr. f. Chir., 1909. e, 101.

30. Esser: München. med. Wchnschr., 1906, liii, 1651. 
BLOOD-PICTURE INDICES

Many observers, including ourselves, have found Arneth's method very cumbersome on account of the multiplicity of detail and on account of its consequent lack of definiteness, which impairs its clinical value. Various suggestions have been made by which the variations in the nucleus of the neutrophils might be noted by a definite index. For this purpose some use as an index simply the number of the neutrophils which are mononuclear, claiming this as a sufficient measure of the shifting to the left. These observers are Zangemeister and Ganz, ${ }^{18}$ Kothe, ${ }^{28}$ Sonnenberg and Kothe $^{29}$ and Kohl. ${ }^{27}$ Others, including Klebs, ${ }^{31}$ Dluski and Rospedzihowski ${ }^{32}$ and Minor and Ringer, ${ }^{33}$ use the sum of Classes 1 and 2 of Arneth's picture as an index.

Adolph Wolf ${ }^{34}$ advocates a total nuclear count of the neutrophils, counting the round segments as one and the bent or loop forms as one and one-half, and in counting he notes only the number of these two types of nuclei and totals them for his nuclear counts. Von Bonsdorf $f^{35}$ has a similar method somewhat modified. Sabrazès ${ }^{36}$ has worked out a neutroleukocytic and neutro-nucleo-leukocytic quotient as an index. Bushnell and Treuholtz ${ }^{37}$ use the sum of Classes 1 and 2 and one-half of Class 3 as an index. In our observations we have followed this suggestion as it seems to lose less of the value of Arneth's original classification than do the others.

\section{TECHNIO}

In our observations the specimens of blood are usually, but not invariably, obtained in the afternoon from three to four hours after the ingestion of food. The other more usual causes of physiological leukocytosis, such as exercise and cold baths, were avoided. Also, no cases were studied after hemorrhage.

We emphasize, as have others, the importance of obtaining thin and even smears of the blood for differential count and of close approximation of the cover slips to the counting chamber for enumeration.

After numerous experiments in various methods of fixing and staining, we found that fixing by drying in the air and passing the slide two or three times across the flame, and the use of Wright's stain made up fresh produced the best results for the study of the nuclei. Enough stain is dropped on the slide to cover the smear, and the dish then covered for one minute. It is most important to have fresh stain often, as Wright's stain does not keep well.

31. Klebs: Am. Jour. Med. Sc., 1906, exxxii, 538.

32. Dluski and Rospedzihowski: Beitr. z. klin. d. Tuberk., 1909, xiv, 259.

33. Minor and Ringer: Am. Jour. Med. Sc., 1911, cxli, 638.

34. Adolph-Wolff: Die Kernzahl der Neutrophilen, Heidelberg, 1906.

35. Von Bonsdorff : Folia Hæmatologica, 1910, ix, 242.

36. Sabrazes: Arch. d. mal. d. cceur, d. vaisseaux et du sang, 1910, iii, 484.

37. Bushnell and Treuholtz: Med. Rec., 1908, lxxiii, 471. 
The slide is left for two or three minutes with the stain, at the end of which time eight or ten drops of tap water are dropped on and the dish again covered for one minute or until the metallic scum appears, when the slide is washed by dipping into a glass of distilled water and out quickly, when it is blotted and dried. All counts should be made with the oil immersion lens.

One hundred neutrophil cells were counted in each observation and the other forms of cells found during this count were noted, so that an average of 140 to 150 leukocytes were counted in each observation.

Many slides were studied by two or three separate observers, and the similarity of the results in the Arneth counting satisfied us that it is an accurate clinical procedure.

In differentiating segments of the nuclei, superimposed segments were always counted separately, as also were those connected by thread. Those having a connecting isthmus, however, were counted as one segment.

\section{EXPERIMENTAL WORK}

Many experiments were carried out to aid in as complete an understanding of the changes found in the white blood-cells as possible, especially in relation to Arneth's studies with the neutrophils.

These experiments can be summarized under the following headings:

1. Staining Experiments: These were undertaken to determine which stain would give the best nuclear picture, and at the same time to differentiate the different classes of leukocytes in the blood.

Smears were prepared in the usual manner except that the slides were clean and as sterile as possible and the blood was spread in a thin and even film. The smears were killed in all the well-known cytological methods and each method of killing and fixing was stained by the three usual differential blood-stains, that is, Wright's differential, Jenner's differential and the eosin and methyl blue method. Many other slides were stained with iron hematoxylin, Ehrlich's triacid stain, and with Goldsmith's triple stain.

The results from these experiments showed that the best method for preparing the slides was to kill the blood-smear by simple drying and to fix and stain with Wright's differential stain, which gave the best nuclear picture as well as differentiated the leukocytes. Jenner's stain does not give a good nuclear stain and fades rapidly, so it was not used.

For the cytological study of the nucleus, slides killed with hot corrosive sublimate and stained with iron hematoxylin gave the best picture. The usual method for the study of the nucleus, i. e., to kill with Flemming strong and stain with iron hematoxylin did not give satisfactory results with the blood-smears. 
2. The Question of Artefacts: These experiments were suggested by Pollitzer's article, ${ }^{16}$ in which an attempt is made to prove that the number of pieces of lobes found in the nucleus of the neutrophils is an artefact and has no connection with the state of the nucleus in the living neutrophil.

(a) Smears were prepared from the blood of three subjects, each of which showed an Arneth index slightly different from the other. These smears were prepared in all the known cytological methods and numbered with a key so that at the time they were counted it was not known from which subject the slide had been prepared. It was found that the smear from each subject gave practically the same index, even where the preparation had been so poor as to be almost useless and that the difference between the indices of the blood-pictures from the three subjects remained the same as in the smears prepared by Wright's differential method.

(b) Smears were prepared in which an attempt was made to stretch and tear the nucleus in order to discover whether there were more or fewer number of lobes to the nucleus than was shown by Wright's differential method. Slides were scratched with emery paper and then cleaned and the blood drawn slowly across the scratches so as to catch and tear the neutrophils.

Counts made from such preparations gave the same neutrophilic bloodpicture as did the smears prepared by the normal Wright's differential method. In some cases the neutrophil was stretched to several times its normal length, but in all such cases the nucleus stretched also and the number of lobes remained the same.

These experiments demonstrate that the number of lobes of the nucleus is not an artifact due to any one stain, but is a definite state taken by the nucleus when killed, which must indicate some definite differences in the state of the nucleus of the different living neutrophils.

3. Normal Blood-Picture in Man and in Guinea-Pigs: (a) Smears were prepared from over twenty different persons whose condition was, as far as known, normal. These different blood-pictures gave indices which varied slightly from each other and yet varied within a small range, which could be called normal. This blood-picture corresponded very nearly with that of Arneth, which was taken from a large number of subjects.

(b) Smears were obtained from a few subjects at different times of day for a period of time extending over a week or several weeks and in two cases extending over a period of two years. The results in these cases show indices which vary, but not definitely enough to be attributed to any one cause, and the amount of the index variation in each case was so slight as still to come within the limits of the normal blood-picture, except in the case of one of the subjects studied for a period of two years, in which the blood-picture shifted decidedly, owing to appendicitis. 
These observations showed that the average normal blood-picture was: I/5, II $/ 26, \mathrm{III} / 36, \mathrm{IV} / 28, \mathrm{~V} / 5$ : leukocytes, 9,000; index, $49: 51$, but that any blood-picture with an index between $45: 55$ and 55:45 may be called normal unless one of the classes should be in some way most unusual.

(c) Ten guinea-pigs were studied for a period of over two weeks. Smears were prepared from the blood of these animals every two hours during the day. The result gave a picture comparable to that of the human blood, except that the number of the lobes of the nucleus of the neutrophil is greater in the guinea-pig than in man, and the index is therefore different. The normal guinea-pig neutrophilic blood-picture is as follows: I/5, II/20, III/38, IV/30, V/6, VI/5 : leukocytes, 10,000; index, $42: 58$.

The blood-picture as shown by the guinea-pig varies more for the individual animal than it did for the individual person, so that in all experiments with guinea-pigs, the animals were kept for a week or ten days and the normal blood-picture established for each animal before the experiment was begun.

4. Effect on Neutrophilic Blood-Picture of Subcutaneous Inoculation of Virulent Culture of Tubercle Bacilli: Guinea-pigs were inoculated subcutaneously with varying amounts of an emulsion of living tubercle bacilli in physiological salt solution. The blood-picture in all cases was very much like the following, except that the number of days was necessary to reach the typical tuberculosis blood-picture varied with the amount used.

\section{Tabie 2,-Blood-Picture of Guinea-Pig VI, Inoculated Three Million Strong Emulsion of Tubercle Bacilli}

Time with Reference I. II. III. IV. V. VI. VII. VIII. Leuko- Index. $\begin{array}{lllllllll}\text { to Inoculation. } & . & \ldots & \ldots & \ldots & \ldots & \ldots & \ldots & \ldots\end{array}$ $\begin{array}{lllllllllll}\text { Before } \ldots \ldots \ldots \ldots & 3 & 21 & 32 & 72 & 6 & 5 & \ldots & \ldots & 9,000 & 40: 60\end{array}$ $\begin{array}{rlrrrrrrrrr}\text { At time of } \ldots \ldots \ldots & 4 & 19 & 36 & 30 & 6 & 5 & \ldots & \ldots & 9,600 & 41: 59\end{array}$ $\begin{array}{lllllllllll}3 \text { hours after..... } & 2 & 14 & 28 & 34 & 12 & 10 & \ldots & \ldots & 10,000 & 30: 70\end{array}$

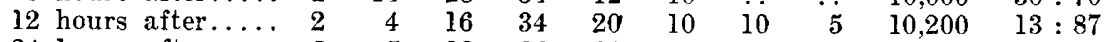

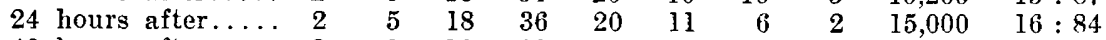
$\begin{array}{llllllllllll}48 \text { hours after..... } & 3 & 9 & 18 & 38 & 16 & 10 & 6 & \ldots & 16,400 & 21: 79\end{array}$

$\begin{array}{lllllllllll}4 \text { days after...... } & 3 & 12 & 33 & 34 & 8 & 3 & 2 & \ldots & 14,000 & 34: 66\end{array}$ $\begin{array}{lllllllllll}8 \text { days after...... } & 4 & 18 & 38 & 30 & 8 & 2 & \ldots & \ldots & 13,200 & 41: 59\end{array}$

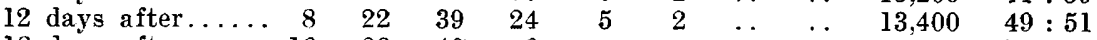

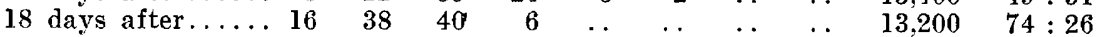

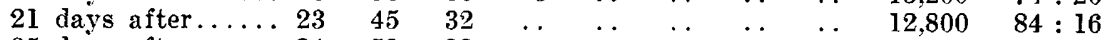

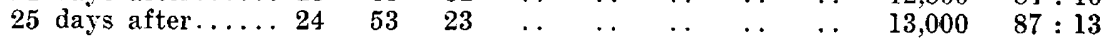

When the animal was killed the lungs and liver were found to be full of tubercles.

These experiments seem to show that while the first result of the inoculation of the tubercle bacilli is to increase the number of neutrophils with the greater number of lobes in the nucleus, the prolonged effect of the bacilli is to use up the neutrophils which have the greater number of 
lobes to the nucleus and leave only those with the fewer number of lobes. The individual whose circulating blood contains an increased number of neutrophils with one or two lobes of the nucleus and a decreased number of neutrophils with four or five lobes is probably not in a state of resistance to the bacteria.

5. The Effect of the Inoculation of Very Small Amounts of Emulsion of Living Tubercle Bacilli: A number of guinea-pigs were inoculated with such a small amount of the bacilli that when killed after several months no trace of tuberculosis was found in the organs of the animal. In these cases the blood-picture showed a very slight increase in the number of lobes of the nucleus following the inoculation. Then the blood-picture either rapidly returned to normal and remained normal or remained with a slight increase in the number of lobes of the nucleus.

6. Blood on Agar with Tubercle Bacilli: A drop of fresh flowing blood was placed on an agar plate and at one edge of the drop was placed a very small amount of tubercle bacilli. The agar plate was kept in the incubator and smears made every five minutes from the side of the drop of the blood near the bacilli as well as from the side of the drop away from the bacilli. The blood-picture showed an increase in the number of lobes of the nucleus of the neutrophils of the blood, which touched the bacilli, even after a period of five minutes, while the neutrophils of the blood away from the bacilli remained normal.

Experiments in which washed leukocytes were used instead of normal blood gave the same result.

7. The Effect of Contamination: (a) Blood was drawn from the end of a finger purposely made dirty and slowly smeared on slides which had been handled and were not clean. In all cases such smears gave a neutrophil blood-picture in which the number of the lobes of the nucleus had increased.

(b) Blood was drawn from a clean finger and placed in small glass chambers which were not sterile and which were left open to the air of the incubator. Smears prepared from such blood after a period of five or ten minutes showed a decided increase in the number of lobes of the nucleus. Neutrophils with as high as ten or twelve lobes to the nucleus were present, while the blood from the same finger normally prepared or kept in sterile dishes in the incubator never contained neutrophils with a nucleus of more than five lobes.

(c) One of the guinea-pigs inoculated with $2,000,000$ weak emulsion of tubercle bacilli developed an open abscess at the point where the needle entered. The smears prepared from the blood of this animal gave the following blood-picture, which shows an irregularity as well as an increase in the number of lobes of the nucleus of the neutrophils. 
Table 3.-Blood-Picture of Guinea-Pig II, Which Developed Abscess Following tife Inoculation of Two Millions of Tubercle Bacilli.

\begin{tabular}{|c|c|c|c|c|c|c|c|c|c|c|}
\hline $\begin{array}{c}\text { Time with Reference } \\
\text { to Inoculation. }\end{array}$ & $\begin{array}{l}\text { I. } \\
. .\end{array}$ & $\begin{array}{l}\text { II. } \\
\text {.. }\end{array}$ & $\begin{array}{c}\text { IrI. } \\
\ldots\end{array}$ & $\begin{array}{l}\text { IV. } \\
. .\end{array}$ & $\begin{array}{l}\text { V. } \\
\therefore\end{array}$ & $\begin{array}{l}\text { VI. } \\
. .\end{array}$ & $\begin{array}{l}\text { VII. } \\
\ldots\end{array}$ & $\begin{array}{l}\text { VIII. } \\
\ldots \ldots\end{array}$ & $\begin{array}{l}\text { Leuko- } \\
\text { cytes, }\end{array}$ & $\begin{array}{l}\text { Index. } \\
\ldots\end{array}$ \\
\hline Before & 4 & 21 & 36 & 30 & $\mathbf{5}$ & 44 & & & 10,000 & $43: 57$ \\
\hline At time of. & 3 & 21 & 35 & 30 & 6 & 5 & & & 10,200 & \\
\hline 3 hours after. & 2 & 16 & 32 & 30 & 8 & 6 & 3 & 3 & 12,000 & $34: 66$ \\
\hline 12 hours after. & 2 & 14 & 30 & 20 & 14 & 10 & 6 & 4 & 14,000 & $31: 69$ \\
\hline 24 hours after. & 3 & 20 & 30 & 18 & 13 & 7 & 5 & 4 & 13,500 & $38: 62$ \\
\hline 48 hours after. & 2 & 21 & 32 & 26 & 10 & 6 & 3 & & 14,000 & $39: 61$ \\
\hline 4 days after. & 3 & 14 & 30 & 26 & 11 & 10 & 4 & 2 & 18,000 & $32: 68$ \\
\hline 8 days after. & 1 & 10 & 33 & 28 & 13 & 7 & 5 & 3 & 16 & $27: 72$ \\
\hline 12 days after & & 4 & 24 & 30 & 15 & 10 & 10 & 7 & 15,000 & $16: 84$ \\
\hline 16 days after. & i2 & 24 & 30 & 20 & 10 & 4 & & & 22,000 & $51: 49$ \\
\hline 18 days aft & & 6 & 16 & 32 & 23 & 13 & 5 & 5 & 16,000 & $14: 86$ \\
\hline 20 days & 4 & 10 & 18 & 34 & 19 & 11 & 4 & & 17,000 & $23: 77$ \\
\hline
\end{tabular}

Animal was killed - liver and lungs contained many tubercles.

8. The Neutrophil Blood-Picture in Opsonic Index Work: Many of the slides studied were obtained through the courtesy of Dr. W. H. Park of the New York Department of Health and others were prepared by us. An emulsion of dead bacilli was used and the pipets were left in the incubator for fifteen minutes.

All such smears gave a blood-picture in which the number of the lobes of the nucleus of the neutrophil was greatly increased. Neutrophils with six, eight, ten, twelve and in one case sixteen lobes to the nucleus were found, while almost no neutrophils with one, two or three lobes were present.

9. Effect of Inoculation with Snake Venom: Inoculation of guineapigs subcutaneously with snake venom gave a neutrophilic blood-picture in which the number of the lobes of the nucleus was decidedly increased. Many neutrophils contained nuclei of so many lobes that they had the appearance of rosettes. The neutrophils of the bone-marrow showed the same change in quite as great an extent as did those of the circulating blood.

\section{CONCLUSTONS FROM EXPERIMENTS}

1. The neutrophil is an organism which reacts quickly and definitely to its environment and this reaction is indicated by the number of lobes of the nucleus.

2. The presence of neutrophils which have a nucleus of a greater number of lobes than normal indicates some reaction to a change in the environment such as the presence of a toxin or of bacilli.

3. The presence of neutrophils which have a nucleus of a less number of lobes than normal indicates either that the neutrophils are being used up and so only those in the younger stage are left in the circulating blood or that the neutrophils entering the blood fail to undergo the metabolic or 
morphologic change which causes the increase in the number of lobes of the nucleus and so remain in the one or two lobe form.

4. The index shown by the neutrophilic blood-picture shows the condition of the neutrophils of the blood and in this way gives an insight into the condition of the subject.

\section{PULMONARY TUBERCULOSIS}

Our observations in pulmonary tuberculosis were made on seventyeight cases with a total of 315 separate blood-counts. The period of time covered by our studies was three years, and this has made it possible to follow many cases of tuberculosis over a long period, which is very important in any effort to draw conclusions from observations made in regard to this disease.

We wish to emphasize strongly the importance of studying the changes of the blood according to the clinical course of the disease and not according to the pathological conditions in the lungs, as has been done by the majority of observers who have reported on the changes in the leukocytes in tuberculosis, many of whom have followed the classification of Grawitz.

We have classified our cases according to the stages of the National Association, and in addition to that, according to the clinical prognosis at the time of the first observation, and have followed these cases into their subsequent history, endeavoring to coordinate our blood findings with the clinical course.

\section{THE NUMBER OF LEUKOCYTES}

The majority of authorities state that the leukocytes are not changed in uncomplicated tuberculosis, but are increased when secondary infection occurs, resulting in caseating lesions or cavity formation, or with exudative inflammation or in some of the complications, such as hemorrhage and enteritis.

Kjer-Petersen ${ }^{5}$ made a particularly careful study of the number of leukocytes in tuberculosis. He comes to the conclusion that the extent of the lesion has no relation to the number of leukocytes; that in men in early stages the number is normal if there is no fever, and in third stage cases with no fever moderately increased but very variable $-6,000$ to 15,000 .

In febrile cases there is some increase in all stages, and particularly those of continuous fever, which he attributes to mixed infection. Other cases of pure tuberculosis with continuous fever are very variable but average low counts. In women, as already stated, he found the count very' variable. 
Stein and Erbmann, ${ }^{38}$ Kjer-Petersen, ${ }^{5}$ Applebaum $^{39}$ and Steffen ${ }^{40}$ think a sudden increase in leukocytes important evidence of cavity formation. Richard, ${ }^{41}$ Bezançon, de $J_{\text {ong }}$ and de Serbonnes ${ }^{4,43}$ and Halbron ${ }^{44}$ and Steffen ${ }^{40}$ emphasize the importance of following the clinical course regardless of the pathology, and found a tendency to leukocytosis with the exacerbations of the disease.

Claude and Zaky ${ }^{45}$ obtained similar results in guinea-pigs, the leukocytes in the controls being increased and in treated animals less so. Ullom and Craig ${ }^{46}$ state that a decrease in the number of leukocytes in advanced cases is unfavorable. Arneth also looks on a leukocytosis as favorable and states that a shifting to the left of his blood-picture is worse if the number of the leukocytes is low. Craig ${ }^{47}$ disagrees with Stein and Erbmann ${ }^{38}$ in the significance of the increase of leukocytes with cavity formation. They found often no leukocytosis in cases of cavity.

Our own results in the enumeration of the total number of leukocytes coincide closely with those obtained by other observers, except that the average obtained in incipient cases and in the non-tuberculous cases is a little higher, 9,874 and 10,209 respectively. There is a distinct increase in the number of leukocytes with the progression of the disease. This is graphically shown in Chart 1 . The striking difference between the nontuberculous $(10,209)$ and the moribund patients $(26,300)$ corresponds with the reports of other observers of the frequent marked leukocytosis in dying patients. The variations according to the stage, the clinical prognosis at the time of observation and the subsequent course of the disease show a distinct relationship between these factors and the number of leukocytes, which the chart shows better than description. The fact that the figures shown for the prognosis correspond quite closely with those for the subsequent history, would appear to make the enumeration of the leukocytes in tuberculosis a procedure of more prognostic value than it is usually considered.

Inasmuch as our cases have been followed in the majority of instances for more than two years since the blood-counts were made, the data presented as to the subsequent history represent accurately the course of the disease.

38. Stein and Erbmann: Deutsch. Arch. f. klin. Med., lvi, 323.

39. Applebaum: Berl. klin. Wchnschr., 1902, xxxix, 7 .

40. Steffen: Deutsch. Arch. f. klin. Med., 1910, xcviii, 355.

41. Richard: Prov. Med., 1908, xix, 205.

42. Bezançon, deJong and de Serbonnes: Arch. d. méd. expér., 1910, xxii, 17.

43. Bezançon et de Serbonnes: Bull. et Mem. Soc. Med. d. hôp. d. Paris, Ser. 3,1910 , xxix, 232 .

44. Halbron: Rev. d. la Tuberc., 1903, x, 319.

45. Claude and Zaky: Rev. d. la Tuberc., 1902, ix, 117.

46. Ullom and Craig: Am. Jour. Med. Sc., 1905, exxx, 386.

47. Craig: Tr. Nat. Assn. Prev. Tub., 1907, iii, 277. 
Table 4.-Blood-Counts in Various Classes of Tubercclous and NoxTurercllous Cases

\begin{tabular}{|c|c|c|c|c|c|c|c|c|c|}
\hline & $\begin{array}{l}\text { No. } \\
\text { of } \\
\text { Cases }\end{array}$ & $\begin{array}{l}\text { No. of } \\
\text { Observ. } \\
\text {. }\end{array}$ & $\begin{array}{l}\text { Aver. } \\
\text { No. } \\
\text { Leuk. }\end{array}$ & $\begin{array}{l}\text { Per } \\
\text { Cent. } \\
\text { Neut. }\end{array}$ & $\begin{array}{l}\text { Aver. } \\
\text { Arneth } \\
\text { Indices. }\end{array}$ & $\begin{array}{l}\text { Per } \\
\text { Cent. } \\
\text { L. L. }\end{array}$ & $\begin{array}{l}\text { Per } \\
\text { Cent. } \\
\text { S. L. }\end{array}$ & $\begin{array}{r}\text { Per } \\
\text { Cent. } \\
\text { Eos. }\end{array}$ & $\begin{array}{l}\text { Per } \\
\text { Cent. } \\
\text { Bas. }\end{array}$ \\
\hline Not tubenc..... & 9 & 37 & 10,209 & 64.4 & $54: 46$ & 17.5 & 11.8 & 5.8 & 0.53 \\
\hline ulmon. tuberc.: & & & & & & & & & \\
\hline Incipient & . 15 & $50-54 \ddagger$ & 9,874 & 72.4 & $64: 36$ & 14.4 & 9.0 & 3.7 & 0.52 \\
\hline Advanced & . 30 & $91-114$ & 10,2 & 74. & $67: 33$ & 15 & 7. & 2. & 0.52 \\
\hline Far adv..... & .20 & $91-101$ & 13,218 & 77.9 & $75: 25$ & 13.9 & 6.2 & 1.5 & 0.44 \\
\hline $\begin{array}{l}\text { Dying from tu- } \\
\text { bercul. other }\end{array}$ & & & & & & & & & \\
\hline $\begin{array}{l}\text { than pulmon.* } \\
\text { Prognosis: }\end{array}$ & * & $8-9$ & 26,300 & 78.5 & $66: 34$ & 17.1 & 4.1 & 0.29 & 0 \\
\hline Good & 19 & $62-79$ & 9,398 & 71. & 60 & 14 & 9. & 3.7 & 0.53 \\
\hline Doubtful & . 18 & $77-$ & 11,5 & 78 & $73: 27$ & 13 & 5. & 2.0 & 0.32 \\
\hline$\ldots \ldots$ & . 29 & $84-99$ & 12,486 & 77.1 & $72: 28$ & 13.4 & 7.5 & 1.6 & 0.35 \\
\hline $\begin{array}{l}\text { Subsequent hist. } \\
\text { of tuberculous } \\
\text { patient: }\end{array}$ & & & & & & & & & \\
\hline roved & 17 & $60-$ & & 71 & & & & & 0.5 \\
\hline Dis. station $\dagger$. & 3 & 18 & 12,4 & & 72 & & & 1.6 & 0.43 \\
\hline Dis. pl & . 26 & $102-1$ & 13,8 & 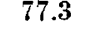 & $74: 26$ & 4.5 & 5.9 & 1.86 & 0.43 \\
\hline
\end{tabular}

* Tuberculosis of kidney, of bladder, of psoas muscle, and acute miliary.

$\uparrow$ Two of these cases were far advanced chronic cases.

\$Complete counts for every point were not invariably made.

\section{POLYNUCLEAR LEUKOCYTES}

Almost all observers have found that when cases of tuberculosis showed a leukocytosis, it was usually of a polynuclear form and it is explained by the incidence of secondary infection. Experimentally, Achard and Loper ${ }^{48}$ found that there was a primary increase in the polynuclears followed by an increase in the mononuclears.

Claude and Zaky ${ }^{45}$ also found that the percentage of polynuclears was much less in treated animals with a tendency to localized lesions than in the control animals. Bezançon, de Jong and de Serbonnes ${ }^{42}$ consider a polynucleosis as significant of acute and active disease and of great value in both prognosis and treatment, stating that all active treatment, such as tuberculin, arsenic, superalimentation, etc., is contra-indicated if polynucleosis is present. They consider it a guide to the dosage of tuberculin similar to the opsonic index. Almost all observers consider an increased percentage of polynuclear an unfavorable sign.

In our own studies the percentage of neutrophils varies from 64.4 per cent. in the non-tuberculous to 78.5 per cent. in the moribund patients. and in general the percentage is higher the more advanced the disease and the more unfarorable the prognosis and subsequent course. All of these percentages are high in our observations, even the incipient cases showing a percentage of 72.4 per cent.

48. Achard and Loeper: Compt. rend. d. Soc. d. biol., 1900, lii, 1066; 1901 , liii, 219 . 
The increase in the more unfavorable cases, however, is very marked and would seem to corroborate the observations of others that the leukocytosis of tuberculosis is due to an increase in the polymorphonuclears. A high percentage of neutrophils would therefore seem from our observations to indicate an unfavorable prognosis, and this would be the more probable were an actual leukocytosis also present.

\section{ARNETH'S BLOOD-PICTURE}

As already stated, unfavorable clinical reports on the value of Arneth's blood-picture in tuberculosis have been made by Paulicek, ${ }^{20}$ Bourmoff and Brugsch, ${ }^{21}$ Solis Cohen and Strickler ${ }^{23}$ and Kagan. ${ }^{22}$ Many other observers, particularly those who have reported more recently, corroborate Arneth's findings in this disease. Among them may be mentioned Klebs, ${ }^{31}$ Sabrazès, ${ }^{36}$ Dluski and Rospedishowski, ${ }^{32}$ Pottenger, ${ }^{49}$ Von Bonsdorf, ${ }^{35}$ Bushnell and Treuholtz, ${ }^{37}$ and Minor and Ringer. ${ }^{33}$

We have already described our method of making the Arneth count and the meaning of the indices recorded in the tables. While we appreciate the fact that the use of these indices is a marked departure from Arneth's own method, we have found from experience that they represent very accurately the main contention, i. e., the shifting to the left in the nuclear blood-pictures. It has been impracticable to tabulate the details of these counts and for that reason only the indices appear and the actual percentage of cells with their different number of nuclear segments is not represented.

We feel that this in no way detracts from the practical value of the results presented, and we are anxious to emphasize our appreciation of these indices, or similar ones, as a valuable addition to the information that may be obtained from the differential leukocyte count. The more cumbersome tables of Arneth would never come into general use, but their chief clinical value is retained in the indices which, because of their definite numerical form, can easily be incorporated into the results of every leukocyte count and probably will be, as soon as their value is more generally appreciated.

Our results are seen in Chart 1, the left-hand number of the index being employed in the chart.

Our average index for the non-tuberculous cases was $54: 46$, and this corresponds closely with those obtained in a considerable number of observations on normal individuals. In all other cases it will be seen that the left-hand number is much larger, and this represents the number of cells with one and two nucleus segments, plus one-half of the number having three segments. It is evident how clearly the shifting to the left is demonstrated in our observations.

49. Pottenger: Jour. Am. Med. Assn., 1909, lii, 1980. 
The degree of shifting also becomes more marked as the cases are more advanced until an average index of $75: 25$ is noted in the far advanced cases. Corresponding to this is the marked shifting noted in the cases with unfavorable prognosis and the subsequent clinical course.

The relatively slight shifting in the four cases of moribund patients is surprising. It is not to be expected from the progressive shift observed in cases with unfarorable course during the period of observation. While it may be that there is a change in the nuclear blood-picture shortly before death, the number of cases of this sort which we have studied is so small that no definite deductions should be drawn from them.

CHART I

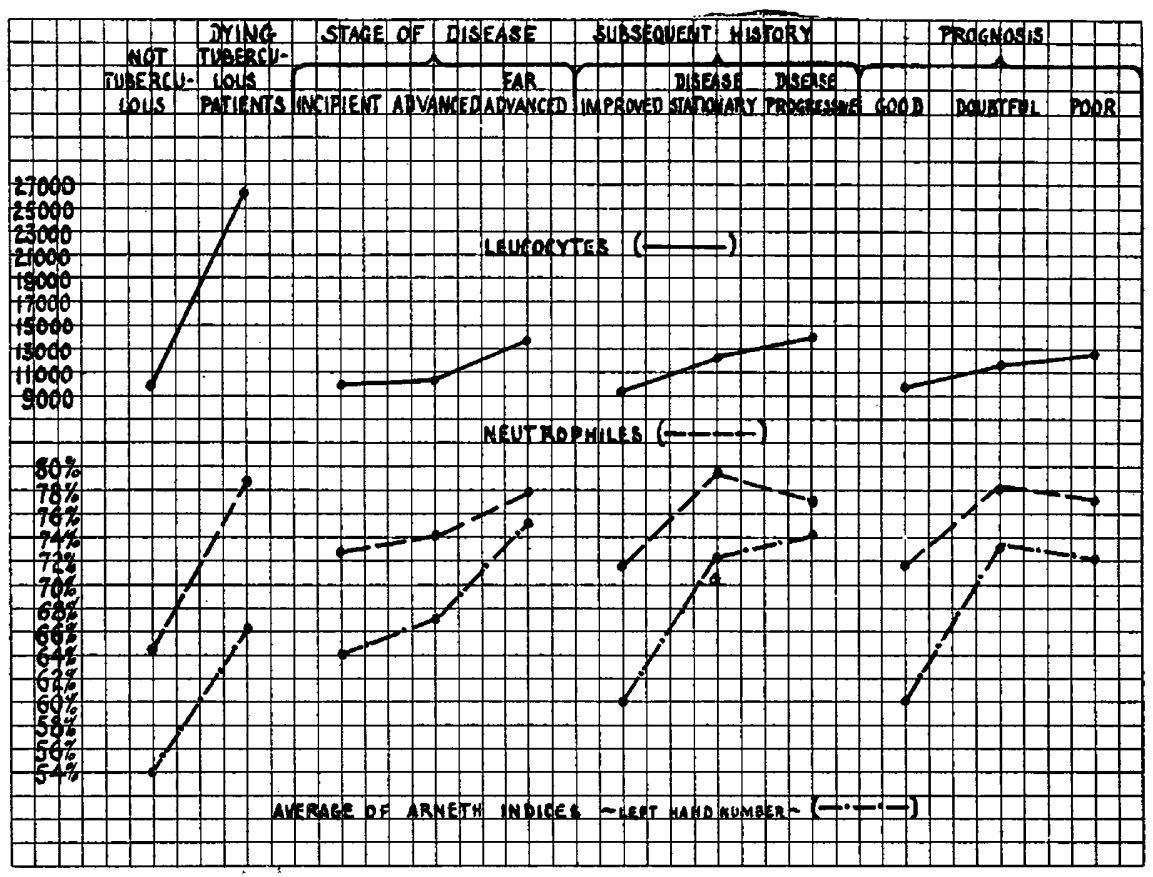

From the general standpoint of diagnosis and prognosis, however, we feel that in the study of the nuclear blood-picture, we have obtained information which is of the greatest value in tuberculosis. The changes noted are more constant than are any of the others in the blood and much more so than are many of the usual clinical signs and symptoms.

In diagnosis the field of usefulness is limited because of the comparatively slight shifting in early cases, and the fact that it may occur in other conditions in which the general condition of the patient is below normal, our experience and that of others being that the shifting to the 
left is simply a response to any deleterious influence in the body, especially the bacterial infections.

In prognosis, however, both at the time of original examination and during the course of the disease, the degree of shifting to the left is an exceedingly sensitive indication of the resisting powers of the individual and of the progress of the disease.

We have found that patients with very slight lesions but persistently presenting an unfavorable nuclear picture almost invariably do badly, and that, on the contrary, those with extensive lesions but fairly good nuclear picture show a marked tendency to resist the disease successfully. Moreover, during the clinical observations of a case, its real progress in one direction or the other can usually be more accurately anticipated by the changes in the nuclear picture than by any other clinical means.

Eren clinical apparent cures, as Arneth well claims, are insecure unless the nuclear picture has come nearly to approach the normal, and our experience has made us very reluctant to advise a return to work and less farorable surroundings in such cases, while such return may be allowed with considerable confidence when a healthy blood-picture is found.

\section{ARNETH'S BLOOD-PICTURE AS A GUIDE TO SPECIFIC TREATMENT}

Arneth asserts that his blood-picture is of great value both as a guide to dosage in tuberculin and also as a test for the effect of the treatment. $\mathrm{He}$ also considers it of value in deciding the question of the necessity for secondary courses of treatment with tuberculin. Uhl ${ }^{50}$ has found it of value in a similar way. Von Bonsdorf also used it as a guide for dosage, and notes a negative phase in the blood-picture after tuberculin similar to that of the opsonic index. Arloing and Genty ${ }^{51}$ have compared the blood taken with the agglutinating power of the serum and also with the results of treatment with Maragliano's and Marmorek's serums and find a general correspondence in the results. Röver ${ }^{52}$ also corroborates these results with Marmorek's serum. Kaufmann, ${ }^{53}$ on the contrary, found no relation between the effects of Marmorek's serum or the clinical course and the changes in Arneth's blood-picture.

In our own work we at first attempted to use Arneth's blood-picture as a guide to tuberculin dosage, and for a while it seemed as though results were encouraging; but later experience has demonstrated to us that it is of little or no value, and that the usual clinical guides are much more consistent and delicate than any changes we have found in the leukocytes.

50. Uhl: Beitr. z. klin. d. Tuberk., 1906, vi, 249.

51. Arloing and Genty: Jour. d. phys. et d. path. gèn., 1910, xii, 236.

52. Röver: Beitr. z. Klin. d. Tuberk., 1906, v, 299.

53. Kaufmann: Beitr. z. Klin. d. Tuberk., 1908, xi, 315. 


\section{THE LYMPHOCYTES}

In a general way, the majority of observers have noted a change in the lymphocytes inversely proportionate to the neutrophils. In consequence, a diminishing number of lymphocytes would be considered unfavorable and an increase correspondingly favorable. Da Costa ${ }^{10}$ asserts that occasionally the leukocytosis of advanced disease is due to lymphocytes. Warthin ${ }^{54}$ also noted this symptom in chronic cases, as does Cabot. ${ }^{6}$ Arloing and Genty, ${ }^{51}$ Richard, ${ }^{41}$ Bezançon, de Jong and de Serbonnes, ${ }^{42}$ Halbron, ${ }^{44}$ Sabrazès, ${ }^{36}$ Steffen, ${ }^{40}$ Ullom and Craig ${ }^{46}$ all consider that an increased percentage is favorable. Steffen ${ }^{40}$ and Bezançon, de Jong and de Serbonnes ${ }^{42}$ lay especial stress on its favorable significance during periods of improvement.

Experimentally, Achard and Loeper ${ }^{48}$ found that secondarily in guinea-pigs there was a Iymphocytosis following a polynucleosis. Claude and Zaky ${ }^{45}$ found that in controls the Iymphocytes were diminished and that in chronic cases and treated patients the large mononuclear cells were increased.

Webb and Williams 9 lay stress on the increase of the large mononuclears in improving cases and as an effect of altitude. They think that the beneficial effects of altitude in tuberculosis may be attributable to this increase.

In our own results we have separated the lymphocytes into the large lymphocytes and the small lymphocytes with the following results:

\section{THE LARGE LYMPHOCXTES}

The proportion of these cells which we have found in our counts is fairly constant in all stages and all degrees of progression of the disease. No apparent relationship to the clinical data can be made out from the slight variations in percentages recorded in Table 1 and charted in Chart 2. It would seem therefore that no clinical importance is to be attached to these cells in tuberculosis.

\section{THE SMALL LYMPHOCYTES}

In sharp contrast to the large lymphocytes a very definite and interesting relationship appears to exist between the small lymphocytes and the clinical manifestations. This is apparent in Table 4 and is shown very graphically in Chart 2 . With the greater extent of the lesion and the unfavorable progress of our cases there is a progressive diminution in the percentage of the small lymphocytes. In the incipient cases, those with good prognosis, those whose subsequent history show improvement and in the non-tuberculous cases the percentage of the cells are found to be uniformly high, varying from 9.0 per cent. to 11.8 per cent. On the

54. Warthin: Med. News, 1896, lxviii, 89. 
other hand, the more advanced and unfavorable cases show percentages from 4.1 per cent. to 6.2 per cent.

The moderately advanced cases and those with doubtful prognosis standing midway between the other classes 7.5 per cent. to 7.9 per cent. It is evident that in our cases the increased percentage of the neutrophils in unfavorable cases has been largely at the expense of the percentages of the small lymphocytes.

\section{CHART II}

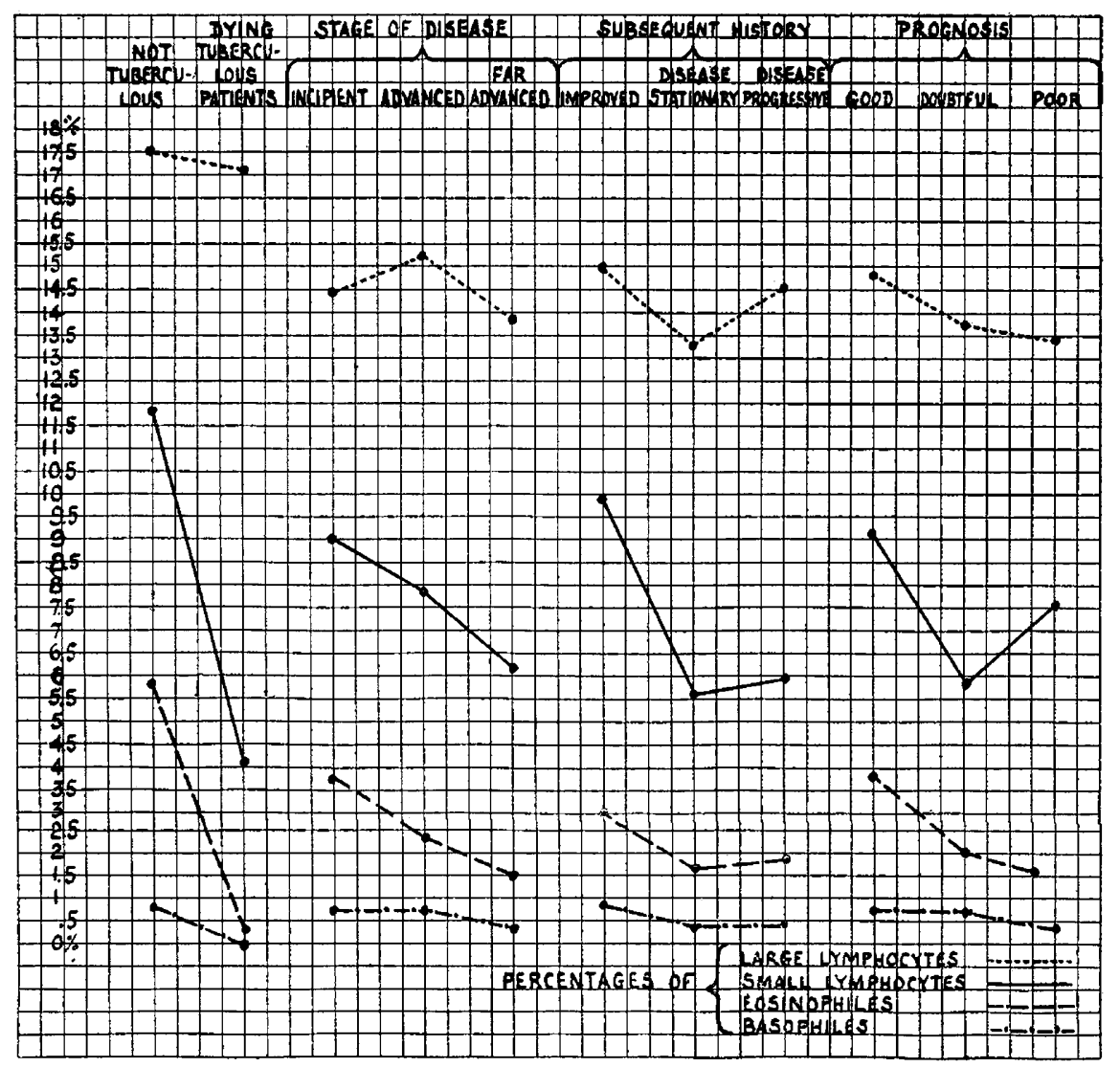

THE EOSINOPHILS

A good deal of emphasis has been laid on the rôle of the eosinophils in the circulating blood as a guide to the clinical condition of the cases of tuberculosis. In general, in acute progressive cases with secondary infection, the eosinophils have been observed to be diminished or absent and to reappear or increase during the periods of improvement or in early and favorable cases. Such is the opinion expressed by Naegeli, Ewing, ${ }^{7}$ 
Swan, ${ }^{55}$ Holmes, ${ }^{56}$ Arloing and Genty, ${ }^{51}$ Sabrazès, ${ }^{36}$ Cabot, ${ }^{6}$ Da Costa, ${ }^{10}$ Zappert, $^{57}$ Galbraith, ${ }^{58}$ Applebaum, Richard, ${ }^{41}$ Steffen $^{40}$ and others. Bezançon, de Jong and de Serbonnes ${ }^{42}$ think that the presence of the eosinophils indicates good resisting power and note their increase in improving cases especially in chronic inactive cases in which they consider that the tubercle bacillus lives in the body as a parasite.

Holbron ${ }^{44}$ asserts that they are diminished in advanced cases and absent in all cavity cases. Neusser ${ }^{59}$ also considers that the increase in eosinophils denotes an immunity to the tubercle bacillus.

Webb and Williams ${ }^{\ominus}$ noted a very slight decrease in advancing cases which, however, was not distinct. Ullom and Craig, ${ }^{46}$ Solis Cohen and Strickler $^{22}$ and Craig ${ }^{47}$ found no relation between these cells and the clinical course of the disease. Experimentally, Claude and Zaky ${ }^{45}$ and Achard and Loeper ${ }^{48}$ found that these cells were diminished in control cases, but reappeared subsequently if the animals lived, and in chronic cases they were increased.

Numerous authorities, including Ewing, ${ }^{7}$ Cabot, ${ }^{6}$ Bischoff, ${ }^{60}$ Rieder $^{61}$ and Bodkin, ${ }^{62}$ note an increase in the eosinophils after the administration of tuberculin.

Our results coincide with the majority of observers, and we have found that with the progression of the disease these cells become less and less numerous until they almost entirely disappear from the blood in the terminal stages.

Our results show 5.8 per cent. in non-tuberculous cases and 3.7 per cent. in the incipient cases and those with good prognosis. This percentage is reduced to 1.5 per cent. in the far-advanced patients and 0.29 per cent. in the moribund patients. Chart 2 shows this relationship very clearly.

\section{THE BASOPHILS}

We have found no reference in literature as to the behavior of the basophil leukocytes in tuberculosis. The small number of these cells found in the blood renders valueless conclusions drawn from the count of from only 100 to 200 cells. The indications, however, are that they do not vary appreciably in the various phases of tuberculosis and that they have no clinical significance.

55. Swan: Jour. Am. Med. Assn., 1904, xlii, 696; Swan and Karsner: New York Med. Jour., 1907, lxxxv, 539.

56. Holmes: Med. Rec., 1896, 1, 3£5; 1897, li, 369; Jour. Am. Med. Assn., 1897, xxix, 828.

57. Zappert: Ztschr. f. klin. Med., 1893, xxiii, 227.

58. Galbraith: Brit. Med. Jour., 1903, i, 600.

59. Neusser: Wien. klin. Wehnschr., 1894, vii, 727.

60. Bischoff: Inaug. Dissert., Berlin, 1891.

61. Rieder: Atlas der klinische Mikroskopie des Blutes, Leipsic, 1907, F. C. W. Vogel; Beitr. z. Kenntniss d. Leukocytosis, Leipsic, 1892, F. C. W. Vogel.

62. Bodkin: Deutsch. med. Wehnschr., 1892, xviii, 321. 


\section{COMPOSITE TUBERCULOSIS BLOOD-PICTORE}

In order easily to appreciate the clinical significance of our findings, we have arranged them in the form of composite blood-pictures for each of the more important features of the disease, in Table 5.

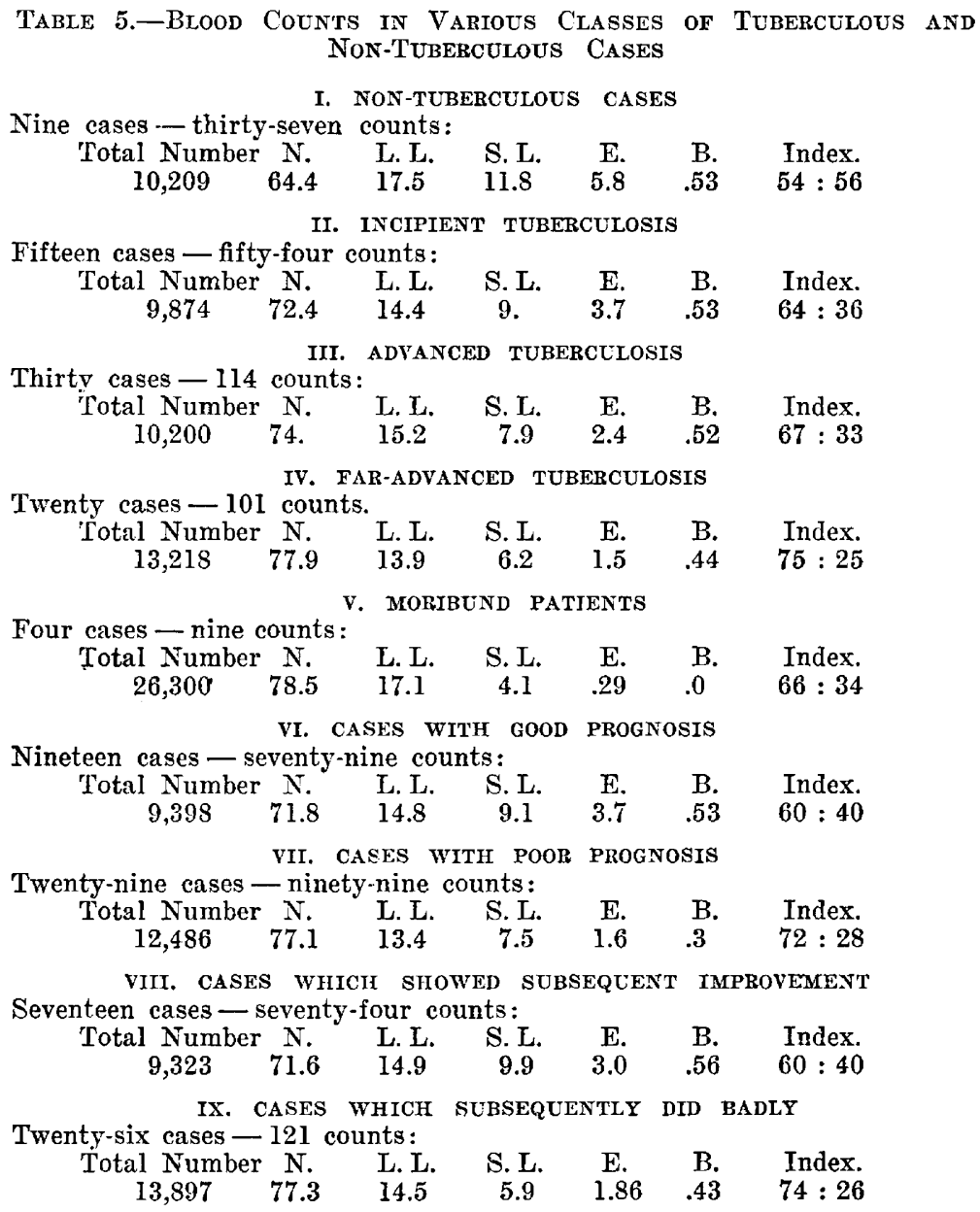

II. INCIPIENT TUBERCULOSIS

Fifteen cases - fifty-four counts:

Total Number N. L. L. S. L. E. B. Index. $\begin{array}{lllllll}9,874 & 72.4 & 14.4 & 9 . & 3.7 & .53 & 64: 36\end{array}$

Thirty cases - 114 counts:

III. ADVANCED TUBERCLLOSIS

Total Number N. L. L. S. L. E. B. Index. $\begin{array}{lllllll}10,200 & 74 . & 15.2 & 7.9 & 2.4 & .52 & 67: 33\end{array}$

IV. FAR-ADVANCED TUBERCULOSIS

Twenty cases - 101 counts.

'Total Number N. $\quad$ L. L. S. L. E. $\quad$ B. Index. $\begin{array}{lllllll}13,218 & 77.9 & 13.9 & 6.2 & 1.5 & .44 & 75: 25\end{array}$

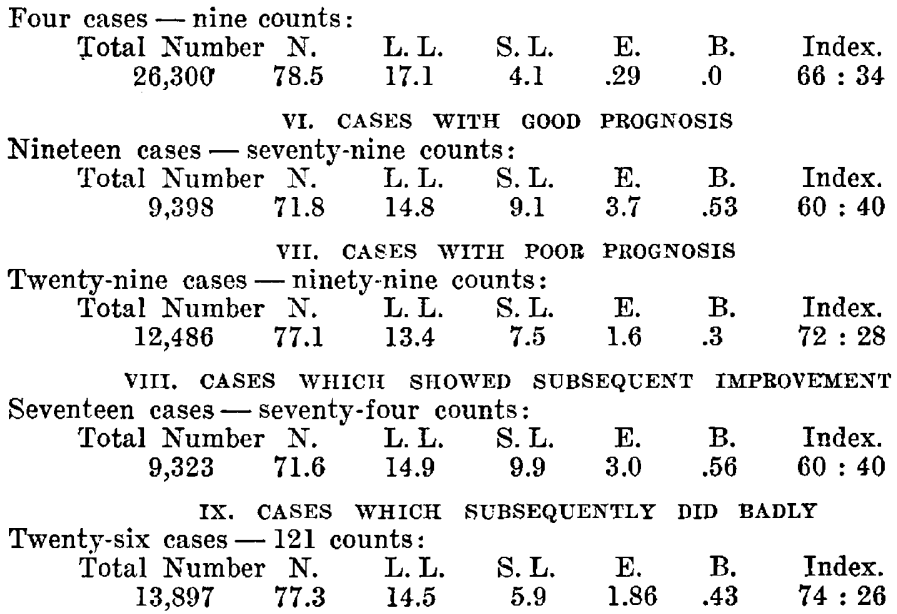

\section{PNEUMONTA}

A review of the literature concerning the behavior of the leukocytes during lobar pneumonia shows that the presence of leukocytosis in this disease has been recognized from the very beginning of blood examinations. Cabot states that the leukocytosis when marked indicates good resistance on the part of the individual or a severe infection, and that a slight leukocytosis or normal leukocyte count indicates a poor resistance or a mild infection. He considers the absence of leukocytosis a very bad 
sign but its presence of no significance for either good or bad. In 842 cases ninety showed no leukocytosis and of these eighty-three were fatal.

Cabot's ideas are similar to those expressed by Ewing, "99 Naegeli," Da Costa, ${ }^{10}$ Buchanan, ${ }^{63}$ and others. Türk ${ }^{2}$ states that the leukocytosis bears no relation to the severity of the disease, and that if it continues after crisis it indicates delayed resolution or some complication.

Rieder $^{61}$ states that it has no relation to the height of the fever. Von Limbeck ${ }^{64}$ states that the leukocytosis is in proportion to the lung involvement. This contention has been disproved by numerous observers. Von $\mathrm{Jaksch}^{6 / 5}$ made a careful study, showing the importance of leukocytosis from the standpoint of prognosis and advocated artificial means to produce leukocytosis such as drugs, local abscess formation, etc. These ideas are now obsolete.

\section{EXPERIMENTAL EVIDENCE}

Tschistovitsch (quoted by Von Limbeck ${ }^{64}$ ) experimented with guineapigs and found that an injection of highly virulent cultures of pneumococcus produced no leukocytosis and the animals died. Weaker cultures produced leukocytosis and the animals recovered.

Rieder $^{\text {e1 }}$ inoculated guinea-pigs intraperitoneally with pneumonia sputum and obtained subnormal leukocyte count and subnormal temperature. Williamson, ${ }^{66}$ by injections of pneumococcus cultures in guinea-pigs, obtained a leukocytosis of varying intensity followed by a diminution in the number of leukocytes. He also noted no relation between leukocytosis and the course of the disease.

\section{CLINICAL STUDY}

Our studies of the leukocytes in pneumonia have failed to reveal the definite clinical relationships that we found in tuberculosis.

Forty cases were studied and on these 131 separate blood counts were made. Almost the entire number were cases of lobar pneumonia, but a few of bronchopneumonia are included. All of the observations were in adults.

In attempting to trace the connections between the blood counts and the clinical findings, we have analyzed the cases according to the extent of involvement, the clinical severity of the infection, the method of defervescence, the duration, the final results and the complications.

Our results in their relation to all of these factors are tabulated in Table 6 .

63. Buchanan: The Blood in Health and Disease, London, 1909, H. Frowde.

64. Von Limbeck: Grundriss einer klinischen Pathologie des Blutes, Jena, 1896, G. Fischer.

65. Von Jaksch: Ztschr. f. klin. Med., 1893, xxiii, 187; Centralbl. f. klin. Med., 1892, xiii, 81.

66. Williamson: Beitr. z. pathol, Anat. und Allg. Path., 1901, xxix, 41.

69. Ewing: New York Med. Jour., 1893, lviii, 713. 


\begin{tabular}{|c|c|c|c|c|c|c|c|c|c|c|}
\hline \multirow{3}{*}{ Inyolyement. } & \multicolumn{3}{|c|}{$\begin{array}{r}\text { 6.-OBSERVATIONS } \\
\text { DURING }\end{array}$} & $\begin{array}{l}\text { IN LOBAH } \\
\text { THE ACUT }\end{array}$ & $\begin{array}{ll}\text { BAR } & \text { AND } \\
\text { UTE ATTA }\end{array}$ & \multicolumn{4}{|c|}{$\begin{array}{l}\text { BRONCHOPNEUMONIA } \\
\text { CK }\end{array}$} & \multirow[b]{2}{*}{$\begin{array}{r}\text { Per } \\
\text { Cent. } \\
\text { Myelo. }\end{array}$} \\
\hline & $\begin{array}{l}\text { No. } \\
\text { of } \\
\text { Cases }\end{array}$ & $\begin{array}{l}\text { No. } \\
\text { Observ. } \\
\ldots \ldots\end{array}$ & $\begin{array}{l}\text { Aver. } \\
\text { No. } \\
\text { Leuk. }\end{array}$ & $\begin{array}{l}\text { Per } \\
\text { Cent. } \\
\text { Neut. }\end{array}$ & $\begin{array}{l}\text { Aver. } \\
\text { Arneth } \\
\text { Indices. }\end{array}$ & $\begin{array}{l}\text { Per } \\
\text { Cent. } \\
\text { L. L. }\end{array}$ & $\begin{array}{l}\text { Per } \\
\text { Cent. } \\
\text { S. L. }\end{array}$ & $\begin{array}{l}\text { Per } \\
\text { Cent. C } \\
\text { Eos. B }\end{array}$ & $\begin{array}{l}\text { Per } \\
\text { Cent. } \\
\text { Bas. }\end{array}$ & \\
\hline & & & & & & & & & & \\
\hline One lobe & 24 & $91-92$ & 17,058 & 77 & $67: 33$ & 16.8 & 4.6 & 1.2 & 0.27 & 0.11 \\
\hline Two lobes & 16 & $35-39$ & 18,012 & 76.5 & $56: 44$ & 17.6 & 4.1 & 1.5 & 0.23 & 0.04 \\
\hline \multicolumn{11}{|l|}{ everity: } \\
\hline Mild & Il & $47-49$ & 17,634 & 76.9 & $66: 34$ & 16.5 & 4.6 & 1.6 & 0.25 & 0.09 \\
\hline Moderate & 13 & $45-46$ & 14,532 & 72.9 & $63: 37$ & 19.5 & 5.3 & 1.8 & 0.42 & 0.08 \\
\hline Severe. & 11 & $28-29$ & 20,250 & 81.8 & $62: 38$ & 15 & 3.0 & 0.08 & 0.3 & 0.07 \\
\hline \multicolumn{11}{|l|}{ Defervescence: } \\
\hline Crisis .... & 21 & $71-74$ & 16,355 & 74.9 & $64: 36$ & 17.6 & 5.2 & 1.9 & 0.23 & 0.14 \\
\hline Lysis & 8 & $30-32$ & 17,028 & 77.5 & $64: 36$ & 17.5 & 3.6 & .77 & 0.48 & 0 \\
\hline \\
\hline $\begin{array}{l}\text { Up to six } \\
\text { days inc... } \\
\text { Seven days }\end{array}$ & 4 & 10 & 16,660 & 72.1 & 66 & 18.7 & 7.8 & 1.4 & 0 & 0.13 \\
\hline and over... & 18 & $17-18$ & 16,912 & 76.4 & $65: 35$ & 17.4 & 4.5 & 1.2 & 0.30 & 0 \\
\hline \multicolumn{11}{|l|}{ Result: } \\
\hline Cured & 12 & 40 & 16,265 & 77.6 & $63: 37$ & 16.5 & 4.9 & 0.89 & 0.077 & \\
\hline Died & 10 & 27 & 21,040 & 80.9 & $60: 40$ & 15.6 & 3.2 & 0.12 & 0.057 & 0.18 \\
\hline $\begin{array}{l}\text { Delayed res- } \\
\text { olution .... }\end{array}$ & 11 & $46-50$ & 15,255 & 73.3 & $66: 34$ & 18.7 & 4.9 & 2.4 & 0.53 & 0 \\
\hline \multirow{3}{*}{$\begin{array}{c}\text { Complications: } \\
\text { Empyema } \\
\text { Pericarditis, } \\
\text { ete. ....... }\end{array}$} & & & & & & & & & & \\
\hline & 3 & 10 & 16,600 & 85.6 & $61: 39$ & 11.3 & 3.0 & 0.008 & & 0 \\
\hline & 6 & $10-11$ & 17,960 & 72.8 & $66: 34$ & 22.5 & 3.7 & 0.66 & 0.26 & 0 \\
\hline \multicolumn{11}{|c|}{ AFTER SUBSIDENCE OF ATTACK } \\
\hline Goo & II & 20 & 12,930 & 73.0 & $59: 41$ & 19.2 & 6.2 & 1.4 & 0.10 & 0 \\
\hline Delayed & 6 & $20-22$ & 12,995 & 64.4 & $64: 36$ & 23.3 & 7.3 & 3.93 & 0.77 & 0.25 \\
\hline
\end{tabular}

In addition, the observations on the leukocytes after the acute infection was over have been studied in respect to the promptness of resolution in the lungs and these results are also included in the table.

TOTAL NCMBER OF LEUKOCYTES

The usual leukocytosis expected in pneumonia was present in our cases but was not as marked as is often seen. The number of leukocytes varied from 15,000 to 20,000 in all classes of cases excepting in the series of ten patients who died, in which the average of twenty-seven counts was 21,040 . This is noteworthy because these results disagree with the more usual finding that a high leukocytosis indicates a good prognosis and a low one the reverse. Our series is too small to enable us to draw definite conclusions in this regard but the results are nevertheless suggestive.

The usual diminution in leukocytosis is noted after the defervescence. This is not so very marked, the counts averaging about 13,000. Most of these counts were made in the first week after defervescence and indicate a gradual return toward the normal leukocyte count. 
In order to ascertain whether there was much variation in the leukocytosis of pneumonia in various years corresponding to the rather general opinion that there is a marked difference in the virulence in this disease at different times, we have collected the records of the leukocyte count in lobar pneumonia for five years, 1904 to 1908 inclusive, of the First Medical Division of Bellevue Hospital. Thus 514 cases are studied and the results are tabulated in Table \%.

Table 7.-Leukocyte Counts in Lobar Pneumonia During Acute Illiness

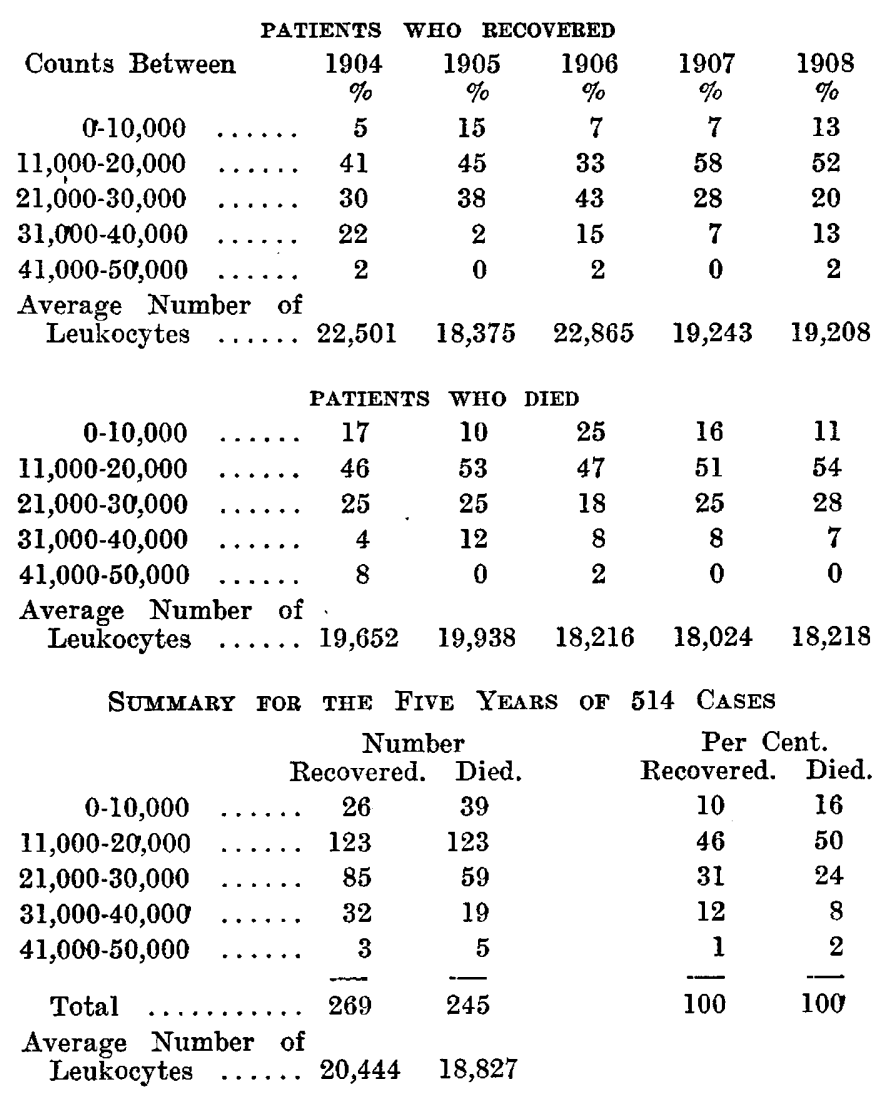

From this table it does not appear that there is any great variation in the various years, certainly none from which any valuable inference could be drawn.

These results also do not demonstrate any definite relationship between fatality and low leukocyte counts. The average for the entire 514 cases showed 20,444 for the patients who recovered and 18,827 for those who died. These cases are all uncomplicated and the counts of course were made by numerous observers. 


\section{DIFFERENTIAL COUNT}

Cabot, ${ }^{6}$ Ewing, ${ }^{7}$ Da Costa, ${ }^{10}$ Türk, ${ }^{2}$ Rieder ${ }^{61}$ and others all find that the leukocytosis of pneumonia is due to the increase of the neutrophils. Türk, who has studied the differential count in pneumonia most thoroughly, states that the neutrophils are increased in proportion to the leukocytosis; that they fall with the crisis but not with a pseudocrisis; that the large mononuclear cells and transitionals vary with the neutrophils; that the lymphocytes may be increased, normal, or diminished in number but that after a crisis they are usually increased; that eosinophils are absent or few during the fever but that their presence is favorable and that after a crisis they are distinctly increased, their reappearance in the blood often being evidence of beginning resolution. Myelocytes may appear if the infection is very acute.

Most authorities agree in general with Türk's observations. Becker ${ }^{67}$ states that he has never found any eosinophils present in fatal cases. Loeper ${ }^{88}$ states that if the percentage of neutrophils is over 90 per cent. the case is almost invariably fatal.

Our observations show that the neutrophils are invariably increased excepting after defervescence; that they vary from 72 to 77 per cent. in all classes of cases excepting in the very severe infections in which they were 81.8 per cent. In patients who died they were 80.9 per cent. and in those who had empyema as a complication, 85.6 per cent.

It would appear therefore that an excessive increase in the percentage of neutrophils indicates a very severe infection. In the lymphocytes our studies fail to reveal any clinical evidence of value. The percentage of large lymphocytes varies from 15 to 23.3 per cent. and the small lymphocytes from 3 to 7.3 per cent.

In the cases of severe infection the percentage of large lymphocytes was comparatively low and higher in those with delayed resolution after defervescence.

In the eosinophil cells the blood counts during the acute illness showed nothing of note, the percentage being normal throughout. In six cases of delayed resolution, however, the average percentage of these cells in twenty counts was 3.93. This moderate increase is in accord with the results of other observers in such cases and appears to have some definite relationship to the condition in the lung.

The basophils and myelocytes were observed in very small numbers and are apparently of no clinical significance.

67. Becker: Deutsch. med. Wchnschr., 1900, xxvi, 558.

68. Loeper: Arch. d. med. exper., 1899, xi, 724. 
THE ARNETH BLOOD-PICTURE

Very few studies of Arneth's blood-picture of pneumonia have been reported. Arneth reports on sixteen cases and notes greater variations in his blood-picture between different cases of pneumonia than in any other infectious disease. There is regularly a marked shifting to the left which may come immediately with the onset or may come on gradually and increase to its highest point just before or after crisis.

Complications, according to Arneth, bring out a new and increased shifting to the left. The blood-picture may return to the normal quickly, corresponding to a rapid resolution, or may continue to get worse at the time of the crisis, even though the total leukocyte count may fall.

Cases defervescing by crisis are more apt to return to normal quickly and those by lysis more slowly. In delayed resolution and chronic interstitial pneumonia, a shifting to the left with a normal or diminished leukocyte count may persist for months. Arneth draws no clinical conclusions of value from his own results.

The observations on our cases show a moderate shifting to the left in the Arneth blood-picture to be a constant factor in our cases of pneumonia. This shifting is less marked than in the more advanced cases of tuberculosis and does not vary in any definite relation to the clinical aspects of the cases studied, the index varying from $60: 40$ to $67: 33$.

Very quickly after defervescence the index tends to go back to the normal if good resolution is established. The average index of all such cases studied was $59: 41$; but these counts were made usually within the two or three days after defervescence, and we have noted in some cases a return to absolute normal nearly coincident with the signs of complete resolution in the lungs.

In the six cases of delayed resolution, however, the average index was $64: 33$, showing the continuation of the shifting to the left in such cases after the fever had subsided, the whole picture in such cases being very similar to that of moderately advanced tuberculosis.

It is to be noted that the least shifting to the left of any clinical group of cases was in the ten patients who died, the average index being $60: 40$.

An unusual average index is noted in Table 2, under the group of sixteen cases with inrolvement of two lobes.

This average does not accurately represent the usual condition of affairs in such cases, but in this series is markedly modified by several observations on one case, which showed a very unusual blood-picture with a marked shifting to the right. This patient died and autopsy showed a marked purulent bronchitis in addition to the unresolved pneumonia.

The index above noted, $60: 40$, for the patient who died, is also influenced by this case, which cannot be considered at all representative of the usual blood-picture found in pneumonia. 
This case is deserving of further consideration as tending to corroborate our experimental observations, that in the presence of a purulent infection the shift may be to the right and the fragmentation of the nucleus becomes very marked in a considerable number of the neutrophils, even up to seven or eight segments.

In general, we have found the determination of Arneth's blood-picture of practically no clinical value in pneumonia.

The composite blood-picture of pneumonia from our results would be:

\begin{tabular}{cccccccc}
\multicolumn{2}{c}{ Total Number. N. } & L. L. & S. L. & E. & B. & M. & Index. \\
17,058 & 77 & 16.8 & 4.6 & 1.2 & 0.27 & 0.11 & $67: 33$
\end{tabular}

The only other composite blood-pictures worthy of separate note in our findings are:

\begin{tabular}{|c|c|c|c|c|c|c|c|}
\hline \multirow{2}{*}{\multicolumn{2}{|c|}{$\begin{array}{r}\text { AFTER } \\
\text { Total Number. N. }\end{array}$}} & \multicolumn{2}{|c|}{ DEFERVESCENCE } & \multirow{3}{*}{$\begin{array}{c}\text { WITH } \\
\text { E. }\end{array}$} & \multirow{3}{*}{$\begin{array}{c}\text { GOOD } \\
\text { B. }\end{array}$} & RESOLUTION & \multirow{2}{*}{ Index. } \\
\hline & & L. I. & S. L. & & & M. & \\
\hline 12,930 & 73 & 19.2 & 6.2 & & & 00 & $59: 41$ \\
\hline \multicolumn{2}{|c|}{ AFTER I } & DEFERVES & ENCE & WITH D & DELAYED & \multicolumn{2}{|c|}{ RESOLUTION } \\
\hline Total Numb & r. N. & L. L. & S. L. & E. & B. & M. & Index. \\
\hline 12,995 & 64.4 & 23.3 & 7.3 & 3.93 & 0.77 & 0.25 & $64: 36$ \\
\hline \multicolumn{8}{|c|}{ CONCLUSIONS } \\
\hline & & $P u$ & $n e$ & & "cul & & \\
\hline
\end{tabular}

1. The study of the leukocytes gives valuable information in the prognosis and clinical course of pulmonary tuberculosis.

2. In diagnosis of incipient cases it is of no assistance but in differential diagnosis of whether more acute pulmonary lesions are due to tuberculosis or some other infection it is sometimes helpful.

3. Arneth's differential neutrophil count is important in tuberculosis.

4. In general, the following changes in the leukocytes occur in cases of pulmonary tuberculosis which are progressively doing badly or are in an exacerbation of the disease:

(a) A leukocytosis.

(b) An increased percentage of neutrophils.

(c) A diminished percentage of small lymphocytes.

(d) A diminished percentage of eosinophils.

(e) A marked shifting to the left of Arneth's blood-picture. Conversely, changes in the opposite direction in any of the above factors are favorable. 


\section{Pneumonia}

1. Leukocytosis occurs as frequently in fatal cases as in those of recovery.

2. This leukocytosis is due to the increased number of neutrophils.

3. When this increase of neutrophils is excessive a very severe infection is indicated.

4. Arneth's differential neutrophil count shows a constant shifting to the left in pneumonia, but it bears no relationship to the clinical course of the disease. 